\title{
Supplementary Outcome-based Resource Material in Reading Comprehension
}

\author{
Jamaica B. Vizcarra and Jeanette G. Dials
}

\begin{abstract}
Using the Research and Development (R\&D) Methodology, this study aimed to develop a supplementary outcome-based resource material in reading comprehension. Specifically, it determined the trend of the National Achievement Test results in English as a basis in the identification of the reading comprehension competencies that were included in the supplementary resource material. It also assessed the validity of the material in terms of its objectives, activities, instructional characteristics and evaluative characteristics.

The main instrument used in the study is the content validation instrument which was later used to validate the content of the supplementary resource material developed. Weighted mean was used in the analysis of the content validation results.

Results showed that the summary evaluation on the characteristics of the outcome-based resource material in reading comprehension acquired a descriptive interpretation of Very Valid. This means that the material generally meets the standards of an outcome-based material. Specifically, the material was evaluated as Very Valid in terms of its objectives, activities, instructional characteristics and evaluative characteristics. Therefore, the resource material is valid in improving the reading comprehension of students.
\end{abstract}

Index Terms-Content validation, outcome-based, reading comprehension, resource material.

\section{INTRODUCTION}

Reading is an indispensable skill that provides opportunities for intellectual growth. Through it, man can access the most significant information that are preserved in books, newspapers, journals and digital texts. It is a basic skill necessary for success in other areas of study. Further, it can lead to a lifetime pursuit of learning, critical thinking, and enjoyment. The ability to read, therefore, is a fundamental goal, as well as a basic tool of education.

With the underlying significance of reading to a person's life, the Department of Education (DepEd) provides various programs that ensure the development and mastery of this skill. However, test results show that students still perform poorly in that area. Contrary to the $97.5 \%$ literacy rate of Filipinos who are 10 years old and above in 2010, the National Achievement Test (NAT) performance in English which measures the reading comprehension of high school students is not impressive.

Manuscript received on June 11, 2017; revised September 10, 2017

J. B. Vizcarra is with the University of Northern Philippines, Vigan City 2700, Ilocos Sur, Philippines (e-mail: jbvizcarra@yahoo.com).

J. G. Dials is with Mariano Marcos University, Laoag City 2907, Ilocos Norte, Philippines (e-mail: jd_0256@yahoo.com).
These suggest that amidst the effort of the department to improve the reading performance of students, there is still a problem with the mastery of the skill. Since NAT for secondary schools is given towards the end of the school year to fourth year students, these students graduate without undergoing necessary remediation to solve their reading difficulties. Such lacking poses a problem when they move up to higher education, especially that solid reading skills would be critical to one's success in college.

Students in college rely on a great amount of reading time to be able to show competence in school; thus failure to do so can be attributed to their poor reading habits. Uychoco found out that the academic reading proficiency of incoming college freshmen only fell under the moderate index which implies that the students are unprepared for college work. Specifically, they are poor on content area reading [1]. Likewise, Manzano found out that the reading competency of BSE and BEEd students in Ilocos Sur is poor [2]. This means that the students have not yet attained the ideal reading competencies for their age and level since they still have poor reading competencies.

These results may be attributed to the existing and unresolved reading deficiencies in basic education. Moreover, materials and other resources used for developing reading comprehension in college and are no longer relevant to the current curriculum and learning styles of the students.

Therefore, a supplementary resource material that is anchored on Outcome-based Approach to Teaching and Learning (OBTL) should be developed to address the reading problems of college students. The said approach which is the new framework to which higher education curriculum is now based will enable students to learn and work on what is necessary through well specified outcomes.

\section{STATEMENT OF PROBLEM}

The study focused on the development of a supplementary outcome-based resource material in reading comprehension based on the NAT results. Specifically, it aims to answer the following questions:

1) What is the trend of the NAT results in English from S.Y. 2010-2011 to 2014-2015?

2) What supplementary outcome-based resource material in reading comprehension may be developed to address the poor reading performance of the students?

3) How valid is the supplementary outcome-based resource material developed in terms of:

(a) objectives; 
(b) activities;

(c) instructional characteristics; and

(d) evaluative characteristics?

\section{REVIEW OF RELATED LiterATURE}

Among the four macro skills, reading is considered as the most accessible skill for the acquisition of knowledge. Anyone can access pieces of information as long as a printed material is available. Known as a receptive skill, it becomes a means for a learner to gather important information that he/she can use in expressing himself /herself whether in a written or oral mode. Indeed, its significance should not be overlook. However, the National Statistics Office (NSO) still identified 1.7 million Filipinos aged 10 and above who cannot read and understand what they read amidst the country's effort in achieving one of the goals of Education for All (EFA) which is the eradication of illiteracy. In 2015, when EFA came to an end, the country wasn't able to reach that target because of the $4 \%$ and $14 \%$ point gaps in the eradication of basic illiteracy and functional illiteracy respectively.

Contrary to the $98.1 \%$ literacy rate of Filipinos who are 15-24 years old in 2013, the National Achievement Test (NAT) performance in English which measures the reading comprehension of high school students is not impressive [3].

This problem continues in higher education. It was discovered that college students perform well in literal comprehension and only average on reorganization, inferential and evaluation comprehension skills [4]. Moreover, future teachers, specifically the BSE students registered the lowest mean scores in reading comprehension [5]. Freshmen have poor schemata in reading so much that they cannot synthesize a reading text, relate previous knowledge to the context of the reading text at hand. It also follows that the respondents might repeatedly read a text until they understand it [6].

The poor ability in reading comprehension affects also the academic performance of students. Reading ability correlates with mathematical performance [7]. The decrease in a student's reading comprehension ability will inevitably lead to a decrease in the amount of learning from texts [8]. Therefore, higher academic achievement requires students to read efficiently and construct meaning on the basis of reading.

Curriculum changes to address the changing needs of leaners and the society. It also changes to solve problems and issues brought about by instruction. The Philippine Higher Education recently underwent change with the integration of Outcome-based Education (OBE) in the curriculum. It focuses and organizes the educational system around what is essential for all learners to know, value and be able to do to achieve the desired levels of competencies. The decisions of the curriculum are then driven by the exit learning outcomes that students should display at the end of the course. OBE is also considered as a results-oriented thinking so the product defines the process [9].

With OBE comes Outcome-based teaching and learning (OBTL) which is a pedagogical approach that focuses on the tasks and competencies that students can demonstrate after they are taught by the instructors. All the curriculums and instructional approaches are designed to best facilitate students to attain the desired learning outcomes [10]. OBTL signifies a paradigm shift from the traditional teaching and learning approach which is teacher-centered and objectives-based, to a student-centered approach under which students are given more autonomy in determining their own learning trajectories and learning goals so that students' learning experiences can be more dynamic [11].

OBTL is different from the traditional teaching and assessment. Traditionally, teachers used to plan their teaching by asking such questions as: What topics or content do I teach? What teaching methods do I use? How do I assess to see if the students have taken on board what I have taught them? Teaching here is conceived as a process of transmitting content to the students, so the methods tend to be expository, and assessment focused on checking how well the message has been received-hence the common use of lectures and demonstrations, with tutorials for clarification, and exams that rely on reporting back [12].

OBTL, on the contrary, is based on questions like: What do I intend my students to be able to do after my teaching that they couldn't do before, and to what standard? How do I supply activities that will help them achieve those outcomes? How do I assess them to see how well they have achieved them? OBTL is not what the teacher is going to teach, but what the outcome of that teaching is intended to be in the form of a statement of what the learner is supposed to be able to do and at what standard.

The shift from traditional pedagogical practices to outcome-based teaching and learning has been lobbied for many years. Various movements such as educational objectives, competency-based, and mastery learning were all bases in the conceptualization of a new framework in curriculum design and teaching and learning practices which is now called the outcome-based education (OBE) approach.

In summary, OBTL put emphasis on systems-level change, observable, measurable outcomes, and the belief that in given time all students can learn.

The innovations and trends in the educational system are emphasizing the role of the student in the teaching-learning process. This is realized through giving extended tasks and activities to students. The activities can serve as reinforcement and/or remediation beyond class hours. Furthermore, these provide opportunities for practice and application of concepts and skills students learned during class time.

One way of promoting student-centered and independent learning is the development and validation of a resource material which aids the student to work on improving his skills through various reading tasks and activities which is likewise the focus of this study. The resource material and its contents had been developed and designed based on the OBTL.

\section{MEthodology}

The development of the supplementary outcome-based resource material was based on the National Achievement Test results in English of the secondary schools attended by 
the students of the University of Northern Philippines-College of Teacher Education (UNP-CTE) S.Y. 2015-2016. The NAT results for the past five years were gathered and interpreted. Furthermore, the 28 secondary schools were identified through purposive sampling.

The $\mathrm{R}$ and $\mathrm{D}$ method was used in developing the supplementary outcome-based resource material. Planning stage identified the activities undertaken by the researchers prior to the development and validation of the resource material. These include the identification of Reading Comprehension Competencies from NAT and the extensive reading on outcome-based approach because this became the basis in the development of the resource material. In addition, reading related studies on the format, technical details and modes of presentation of the resource material was also undertaken.

The development stage covered the writing of the content validation instrument for the outcome-based resource material; validation of the instrument for the outcome-based resource material; writing the resource material; preliminary evaluation of the resource material; and preliminary revision of the resource material.

In the validation stage, the material was content validated by five specialists along its a) objectives; b) activities; c) instructional characteristics; and d) evaluative characteristics. The level of validity was categorized into Very Highly Valid, Highly Valid, Moderately Valid, Slightly Valid, and Not Valid. Weighted mean was used for the analysis of the content validation the comments and suggestions were accepted and applied in the final revision of the resource material.

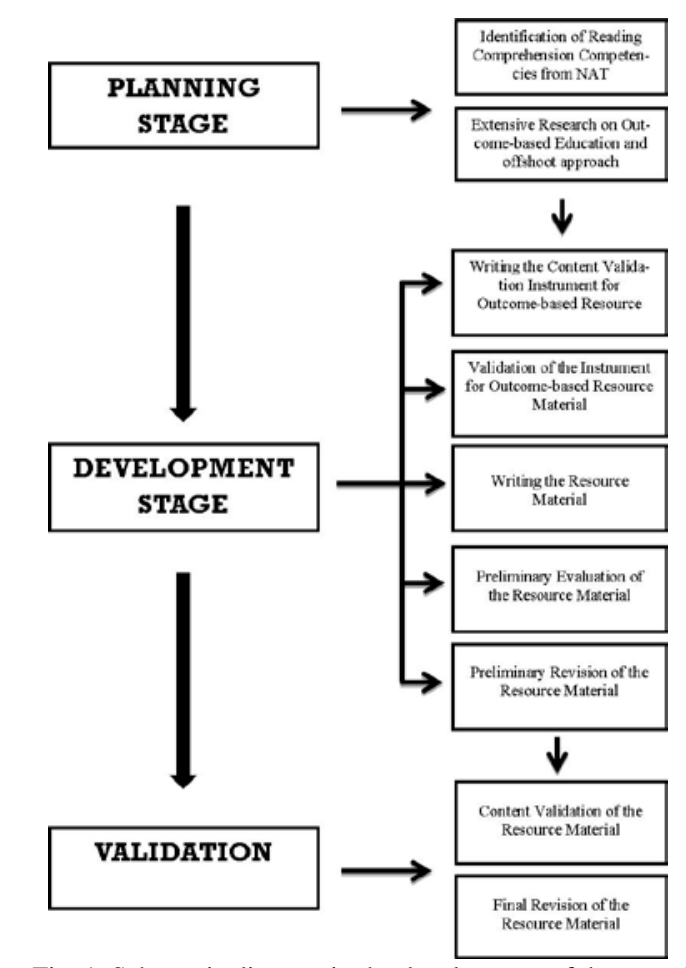

Fig. 1. Schematic diagram in the development of the material.

\section{REsUlts AND Discussions}

Table I presents the mean percentage scores (MPS) and ratings which indicate the trend of the English NAT results of the schools in Vigan City and Ilocos Sur attended by the CTE students in S.Y. 2010-2011 to 2014-2015.

It can be observed that the trend of the average MPS for all the schools in the two divisions is evidently fluctuating. The increase and decrease of the mean percentage scores in the successive years show irregular development in the performance of the students in English and reading comprehension.

In the span of five years, majority of the schools' MPS did not reach $50 \%$ mastery and only two schools managed to reach 75\% and above in 2011-2012 and 2013-2014. It can further be noted that the highest average MPS of 55.02 was acquired in S.Y. 2013-2014 and the lowest MPS of 41.19 was acquired the following year (2014-2015). In general, the average mean percentage scores fall within the range of $35-65 \%$ which were described as having average mastery.

The developed resource material in reading comprehension which is anchored on Outcome-based Approach is proposed as a supplementary material for college students who manifest difficulties in reading comprehension. The resource material intends to help students be more independent in improving their deficient reading skills. The reading competencies included in the material are based on the NAT and these are: noting details, defining words thru word analysis and context clues, deducing the theme/main idea of the selection, interpreting figurative language used, interpreting non-prose forms, making inferences and making predictions.

Unlike other materials found in the market or distributed in educational institutions, the resource material is different since it was based and developed using the latest approach required in higher education which is the Outcome-based Approach.

The material features particular learning outcomes that are tailor-fitted to the reading competencies reflected in the NAT. It also presents general learning outcomes and three specific learning outcomes that guide the student in accomplishing what is expected of him after the lesson. The activities were carefully conceptualized and arranged to fit the identified learning outcomes. Moreover, these come in varied types and difficulties so sustain the interest and challenge the students on reading comprehension.

Another feature of the material is the graphic markers that simply identify the part of the lesson. The student will not have difficulty in going through the material because of these. The material also presents texts and selections that are contemporary and contextualized. In addition, the topics are relevant and interesting as these were anchored to significant issues in the country and in the world.

Using the principles of outcomes - based approach, the material was developed with following parts: (1) Learning outcomes; (2) Focus; (3) Practice; (4) Apply; (5) Assess; (6) Pair-up; (7); Skill check; and (8) Extended readings. The material also contains a teacher's guide which is primarily a manual for the instructor to use.

Learning Outcome presents the intended learning outcome (ILO) or the actions/performances that the student has to demonstrate at the end of the lesson. 
TABLE I: NAT RESULTS IN ENGLISH FROM SY 2010-2011 TO 2014-2015

\begin{tabular}{|c|c|c|c|c|c|c|c|c|c|c|}
\hline \multirow{2}{*}{ School } & \multicolumn{2}{|c|}{$2010-2011$} & \multicolumn{2}{|c|}{ 2011-2012 } & \multicolumn{2}{|c|}{$2012-2013$} & \multicolumn{2}{|c|}{ 2013-2014 } & \multicolumn{2}{|c|}{$2014-2015$} \\
\hline & MPS & Rating & MPS & Rating & MPS & Rating & MPS & Rating & MPS & Rating \\
\hline 1 & 40.5 & A & 41.59 & $\mathrm{~A}$ & 45.27 & $\mathrm{~A}$ & 51.70 & A & 38.74 & A \\
\hline 2 & 54.33 & A & 59.26 & A & 48.46 & A & 67.47 & MTM & 44.50 & A \\
\hline 3 & 48.79 & A & 60.82 & A & 57.89 & A & 58.62 & A & 38.50 & A \\
\hline 4 & 39.48 & A & 50.08 & A & 53.90 & A & 80.73 & MTM & 37.89 & A \\
\hline 5 & 29.61 & $\mathrm{~L}$ & 38.63 & A & 41.38 & A & 45.27 & A & 31.44 & $\mathrm{~L}$ \\
\hline 6 & 36.24 & A & 42.94 & A & 41.51 & A & 47.88 & A & 35.30 & A \\
\hline 7 & 34.28 & $\mathrm{~L}$ & 53.99 & A & 39.31 & A & 52.88 & A & 33.33 & $\mathrm{~L}$ \\
\hline 8 & 38.35 & A & 40.42 & A & 46.30 & A & 47.66 & A & 39.58 & A \\
\hline 9 & 33.67 & $\mathrm{~L}$ & 68.43 & MTM & 63.54 & A & 66.35 & MTM & 41.97 & A \\
\hline 10 & 34.29 & $\mathrm{~L}$ & 36.14 & A & 43.51 & A & 46.55 & A & 38.74 & A \\
\hline 11 & 31.89 & $\mathrm{~L}$ & 37.12 & A & 43.24 & A & 46.55 & A & 33.41 & $\mathrm{~L}$ \\
\hline 12 & 30.19 & $\mathrm{~L}$ & 59.26 & A & 44.37 & A & 70.75 & MTM & 37.03 & A \\
\hline 13 & 60.58 & A & 47.88 & A & 71.29 & MTM & 65.23 & MTM & 44.59 & A \\
\hline 14 & 36.25 & A & 40.19 & A & 43.82 & A & 45.98 & A & 32.38 & $\mathrm{~L}$ \\
\hline 15 & 35.01 & A & 37.29 & A & 37.46 & A & 41.43 & A & 31.95 & $\mathrm{~L}$ \\
\hline 16 & 56.26 & A & 29.76 & $\mathrm{~L}$ & 33.38 & $\mathrm{~L}$ & 34.61 & $\mathrm{~L}$ & 52.95 & A \\
\hline 17 & 60.61 & A & 35.64 & A & 33.13 & $\mathrm{~L}$ & 74.56 & MTM & 43.93 & A \\
\hline 18 & 35.28 & A & 40.58 & A & 34.60 & $\mathrm{~L}$ & 50.00 & A & 36.87 & A \\
\hline 19 & 38.31 & A & 40.38 & A & 36.02 & A & 41.24 & A & 32.93 & $\mathrm{~L}$ \\
\hline 20 & 38.70 & A & 39.63 & A & 40.72 & A & 72.61 & MTM & 59.38 & A \\
\hline 21 & 66.55 & MTM & 60.30 & A & 56.55 & A & 65.07 & MTM & 44.57 & A \\
\hline 22 & 33.69 & $\mathrm{~L}$ & 43.39 & A & 40.15 & A & 45.13 & A & 60.09 & A \\
\hline 23 & 50.20 & A & 49.04 & A & 58.72 & A & 51.24 & A & 61.64 & A \\
\hline 24 & 37.23 & A & 43.66 & A & 49.59 & A & 57.48 & A & 39.28 & A \\
\hline 25 & 35.93 & A & 38.80 & A & 41.12 & A & 48.10 & A & 46.51 & A \\
\hline 26 & 36.37 & A & 42.87 & A & 36.38 & A & 46.26 & A & 32.60 & $\mathrm{~L}$ \\
\hline 27 & 48.22 & A & 78.00 & MTM & 68.30 & MTM & 76.90 & MTM & 50.00 & A \\
\hline 28 & 41.96 & A & 48.44 & A & 49.12 & A & 42.41 & A & 33.14 & $\mathrm{~L}$ \\
\hline AVE & 41.53 & A & 46.59 & A & 46.39 & A & 55.02 & A & 41.19 & A \\
\hline
\end{tabular}

The ILO's embody and reflect the learner's competence in using content, ideas and reading tools successfully. It also includes specific learning outcomes that help the student to realize the ILO. This is anchored to the basic principle of OBE according to Spady which states that curriculum should be designed backwards where "exit outcomes" should be identified first to establish a guided flow of learning

Focus provides short but substantial discussion of the skill that can aid the student in accomplishing the reading tasks that follow in the material without being dependent on the teacher. This part includes helpful tips and hints that the student can use in reading. This is similar to one feature of OBE identified by Malan. According to him, the focus shifts from teaching to learning; the approach is student-centered where lecturers act as facilitators.

Practice contains the tasks and activities that allow the student to have a run-through of the concepts and tips acquired in the previous part.

Apply provides reading activities that require critical and creative thinking to demonstrate what the student learned and developed from Focus and Practice.

The presentation of various tasks in Practice and Apply is supported by the OBE characteristics that opportunities are provided for each learner to achieve his/her ultimate potential; a variety of opportunities are offered to learners to demonstrate whether the outcome has been attained, and learner progression is based on demonstrated achievements (Pretorius, 1998). Likewise, Spady (1998) believed that expanded opportunities provide for a flexible approach in allowing a learner to succeed.

Assess contains the summative assessment of the lesson. It aims to measure the success of the student in meeting the intended learning outcome. According to Biggs and Tang (2006), assessment task is one of the components of the outcome-based approach. It intends to judge how well the task has been performed and by implication, how well the ILO has been met by the student's performance.

Aside from the major parts, the material also includes the following sections:

Pair Up presents an activity that requires the student to work with another student.

Skill Check contains a ten item quiz that tests the competency of the student on a given sub-skill.

Extended Readings for Practice is a collection of different reading selections that is followed by comprehension questions that the student need to answer to check his understanding of the texts.

Teacher's Guide presents the additional references and activities to aid students with little progress. It also contains the answers, criteria and rubrics for checking the outputs.

Table II shows the evaluation of the experts on the objectives of the developed material. It can be observed that the objectives of the resource material had an overall mean of 4.59 which is described as Very Highly Valid. This means that all the learning outcomes of the seven lessons of the material were written according to the characteristics of outcome-based approach objectives. The outcomes are clear, brief, explicit, and measurable. Moreover, these use only one action verb, are aligned with the activities and assessments, and are written in terms of what the learner will do, not what the instructor will do. Therefore, the learning outcomes of the material are valid. 
TABLE II: MEAN RATING OF THE OBJECTIVE (LEARNING OUTCOMES) OF THE SUPPLEMENTARY OUTCOME-BASED RESOURCE MATERIAL

\begin{tabular}{|c|c|c|}
\hline Criteria & $\begin{array}{l}\text { Component } \\
\text { Mean }\end{array}$ & $\begin{array}{c}\text { Descriptive } \\
\text { Interpretation }\end{array}$ \\
\hline \multicolumn{3}{|l|}{ The learning outcomes } \\
\hline 1. are brief and concise. & 4. 67 & $\begin{array}{c}\text { Very Satisfactory/ } \\
\text { Highly Valid }\end{array}$ \\
\hline 2. specify appropriate & & Satisfactory/ \\
\hline conditions for performance.. & 4.33 & Highly Valid \\
\hline $\begin{array}{l}\text { 3. are aligned with the } \\
\text { instructional activities and } \\
\text { assessments. }\end{array}$ & 4.00 & $\begin{array}{l}\text { Satisfactory/ } \\
\text { Highly Valid }\end{array}$ \\
\hline $\begin{array}{l}\text { 4. are written in terms of } \\
\text { observable and measurable } \\
\text { behavioral outcomes. }\end{array}$ & 4.67 & $\begin{array}{l}\text { Very Satisfactory/ } \\
\text { Very Highly Valid }\end{array}$ \\
\hline $\begin{array}{l}\text { 5. use only one action verb and } \\
\text { target one specific aspect of } \\
\text { expected performance. }\end{array}$ & 5.00 & $\begin{array}{l}\text { Very Satisfactory/ } \\
\text { Very Highly Valid }\end{array}$ \\
\hline $\begin{array}{l}\text { 6. are doable and consider } \\
\text { prior knowledge, available time } \\
\text { and learning opportunities }\end{array}$ & 4.67 & $\begin{array}{l}\text { Very Satisfactory/ } \\
\text { Very Highly Valid }\end{array}$ \\
\hline $\begin{array}{l}\text { 7. are written in terms of what } \\
\text { the learner will do, not what the } \\
\text { instructor will do. }\end{array}$ & 4.67 & $\begin{array}{l}\text { Very Satisfactory/ } \\
\text { Very Highly Valid }\end{array}$ \\
\hline $\begin{array}{l}\text { 8. are clear and written in } \\
\text { language that is understandable } \\
\text { to students. }\end{array}$ & 4.67 & $\begin{array}{l}\text { Very Satisfactory/ } \\
\text { Very Highly Valid }\end{array}$ \\
\hline Overall Mean & 4.59 & $\begin{array}{l}\text { Very Satisfactory/ } \\
\text { Very Highly Valid }\end{array}$ \\
\hline
\end{tabular}

The developed material was also evaluated in terms of its activities. The activities provided instructional opportunities in achieving the desired outcomes so these were meticulously constructed. Table III shows that the activities in the resource material passed all the outcome-based criteria as shown by the overall mean of 4.57 which has a descriptive interpretation of Very Highly Valid. This implies that the activities are authentic and interesting. This is in conformity to Nunan's claim that materials should be authentic in terms of text and tasks. This also affirms Tomlinson's principles of material development that materials should include interesting and engaging tasks; and should include authentic language. They also acknowledge the progression of skills that why they come in different difficulty levels. The material also includes activities that facilitate metacognition and knowledge construction, that can be mapped to one or more intended learning outcomes or vice versa and that are designed to address all the intended learning outcomes.

Table IV presents the evaluation of the validators on the instructional characteristics of the resource material. As shown in the table, the overall mean of the instructional characteristics is 4.53 described as Very Highly Valid. This means that the material promotes participation that makes learning more active. It also presents topics in a logical sequence which is important for the student's organized processing of information and skills. In addition, instructions are clear and easy to follow and understand. They also arouse the interest of the learners and sustain attention of the learners.
TABLE III: MEAN RATING OF THE ACTIVITIES OF THE SUPPLEMENTARY OUTCOME-BASED RESOURCE MATERIAL

\begin{tabular}{lcl}
\hline \hline \multicolumn{1}{c}{ Criteria } & $\begin{array}{c}\text { Component } \\
\text { Mean }\end{array}$ & \multicolumn{1}{c}{$\begin{array}{c}\text { Descriptive } \\
\text { Interpretation }\end{array}$} \\
\hline The activities & 4.33 & $\begin{array}{l}\text { Satisfactory/ } \\
\text { Highly Valid }\end{array}$ \\
$\begin{array}{l}\text { 9. are authentic. } \\
\text { 10. are interesting. }\end{array}$ & 4.67 & $\begin{array}{l}\text { Very Satisfactory/ } \\
\text { Very Highly Valid }\end{array}$ \\
$\begin{array}{l}\text { 11. come in different } \\
\text { difficulty level }\end{array}$ & 5.00 & $\begin{array}{l}\text { Very Satisfactory/ } \\
\text { Very Highly Valid }\end{array}$ \\
$\begin{array}{l}\text { 12. promote student's } \\
\text { independence in learning }\end{array}$ & 4.67 & $\begin{array}{l}\text { Very Satisfactory/ } \\
\text { Very Highly Valid }\end{array}$ \\
$\begin{array}{l}\text { 13. facilitate metacognition } \\
\text { and knowledge }\end{array}$ & & Satisfactory/ \\
$\begin{array}{l}\text { 14. (each learning activity) } \\
\text { can be mapped to one or more } \\
\text { intended learning outcomes } \\
\text { (ILOs) or vice versa. }\end{array}$ & 4.33 & Highly Valid \\
$\begin{array}{l}\text { 15. (the different activities) } \\
\text { are designed to address all the }\end{array}$ & 4.33 & Satisfactory/ \\
ILOs. & & \\
\hline \begin{tabular}{l} 
Overall Mean \\
\hline
\end{tabular} & 4.67 & Very Satisfactory/ \\
\hline
\end{tabular}

TABLE IV: MEAN RATING OF THE INSTRUCTIONAL CHARACTERISTICS OF THE SUPPLEMENTARY OUTCOME-BASED RESOURCE MATERIAL

\begin{tabular}{lcc}
\hline \hline \multicolumn{1}{c}{ Criteria } & $\begin{array}{c}\text { Component } \\
\text { Mean }\end{array}$ & $\begin{array}{c}\text { Descriptive } \\
\text { Interpretation }\end{array}$ \\
\hline $\begin{array}{l}\text { The instructional } \\
\text { characteristics }\end{array}$ & & Satisfactory/ \\
$16 . \quad$ promote participation & 4.33 & Highly Valid \\
$\begin{array}{l}17 . \quad \text { present topics in a logical } \\
\text { sequence. }\end{array}$ & 4.33 & $\begin{array}{c}\text { Satisfactory/ } \\
\text { Highly Valid }\end{array}$ \\
$\begin{array}{l}\text { 18. use appropriate and } \\
\text { various reading texts. }\end{array}$ & 4.67 & $\begin{array}{c}\text { Very Satisfactory/ } \\
\text { Very Highly Valid }\end{array}$ \\
$\begin{array}{l}\text { 19. are clear and easy to } \\
\text { follow and understand. }\end{array}$ & & $\begin{array}{c}\text { Very Satisfactory/ } \\
\text { Very Highly Valid }\end{array}$ \\
$\begin{array}{l}\text { 20. arouse the interest and } \\
\text { sustains attention of the } \\
\text { learners. }\end{array}$ & 5.00 & Satisfactory/ \\
\hline Overall Mean & 4.33 & Highly Valid \\
\hline \hline
\end{tabular}

Table V shows that the assessment tasks presented in the resource material passed the outcome-based criteria for its evaluative characteristics. It cane observed that the evaluative characteristics of the material acquired an overall mean of 4.53 which is described as Very Highly Valid. The validators agree that the assessment tasks are valid, doable and manageable, reliable indicator of learner's progress, and aligned with the ILO and require communication of knowledge and/or skills through written and artistic products.

Table VI presents the overall evaluation of the outcome-based resource material. It can be gleaned from the table that the component means of 4.59, 4.57, 4.53 and 4.53 for objectives, activities, instructional characteristics and evaluative characteristics respectively all acquired a Very 
Highly Valid descriptive rating. This implies that the developed resource material is valid in terms of objectives, activities, instructional characteristics and evaluative characteristics therefore the material generally meets the standards of an outcome-based resource material.

TABLE V: MEAN RATING OF THE EVALUATIVE CHARACTERISTICS OF THE SUPPLEMENTARY OUTCOME-BASED RESOURCE MATERIAL

\begin{tabular}{lcc}
\hline \hline \multicolumn{1}{c}{ Criteria } & $\begin{array}{c}\text { Component } \\
\text { Mean }\end{array}$ & $\begin{array}{c}\text { Descriptive } \\
\text { Interpretation }\end{array}$ \\
\hline The assessment tasks & 4.33 & $\begin{array}{c}\text { Satisfactory/ } \\
\text { Highly Valid }\end{array}$ \\
$\begin{array}{l}\text { 21. are valid. } \\
\text { 22. are doable and } \\
\text { manageable. }\end{array}$ & 4.67 & $\begin{array}{c}\text { Very Satisfactory/ } \\
\text { Very Highly Valid }\end{array}$ \\
$\begin{array}{l}\text { 23. } \quad \text { are reliable indicator of } \\
\text { learner's progress. }\end{array}$ & 4.67 & $\begin{array}{c}\text { Very Satisfactory/ } \\
\text { 24. are aligned with the } \\
\text { intended learning outcome }\end{array}$ \\
$\begin{array}{l}\text { 25. require communication } \\
\text { of knowledge and/or skills } \\
\text { through written and artistic } \\
\text { products. }\end{array}$ & 4.67 & $\begin{array}{c}\text { Very Satisfactory/ } \\
\text { Overall Mean }\end{array}$ \\
\hline \hline
\end{tabular}

TABLE VI: SUMMARY OF THE SPECIALISTS' EVALUATION ON THE OUTCOME-BASED RESOURCE MATERIAL

\begin{tabular}{lcc}
\multicolumn{2}{c}{ OUTCOME-BASED RESOURCE MATERIAL } \\
\hline \hline & $\begin{array}{c}\text { Component } \\
\text { Mean }\end{array}$ & $\begin{array}{c}\text { Descriptive } \\
\text { Interpretation }\end{array}$ \\
\hline $\begin{array}{l}\text { A. Objectives } \\
\text { B. Activities }\end{array}$ & 4.59 & Very Highly Valid \\
C. Instructional & 4.57 & Very Highly Valid \\
Characteristics & 4.53 & Very Highly Valid \\
D. Evaluative & 4.53 & Very Highly Valid \\
Characteristics & 4.56 & Very Highly Valid \\
\hline \multicolumn{2}{l}{ Overall Mean } \\
\hline \hline
\end{tabular}

\section{CONCLUSION}

Based on the findings of the study, it can be concluded the students only show average mastery of the reading comprehension competencies which should have been completely mastered at their level therefore there is a need for a supplementary resource material in reading comprehension for college students. Hence, a resource material based on the principles of Outcome-based Education is developed. Moreover, the resource material is valid in terms of objectives, activities, instructional characteristics and evaluative characteristics. The material is valid to enhance reading comprehension thus it can be used to address the poor reading performance of students.

\section{RECOMMENDATION}

From the findings and conclusions made, the researcher offers the following recommendations to basic education teachers and administrators, college instructors and administrators, and research enthusiasts.

The developed resource material in reading comprehension must be tried out to college students who show reading comprehension deficiencies in order to determine its usefulness and effectiveness. The results of the try-out must be analyzed, interpreted and used as a basis for the refinement and further validation of the resource material.

Students are encouraged to use the supplementary resource material to enhance their reading comprehension. Moreover, they should invest more time and effort in working on the reading deficiencies they have inasmuch that reading is a skill that is critical to their educational success.

Teachers and researchers are encouraged to use outcomes-based approach in developing instructional materials for higher education students. Moreover, it should be used in the conceptualization of techniques and activities needed for classroom instruction.

Basic education administrators and teachers should create and develop more reading programs and activities to address the poor performance of students in the National Achievement Test. These programs and activities may include content reading in all subjects, reading a selection a day and summer reading classes. Through the conduct of these, the percentage of student population showing low and average mastery in the competencies can be decreased.

Administrators should mandate the use of outcome-based approach in the curriculum. This can be achieved through the conduct of seminars on OBE and its application to teaching and learning; and professional workshops and trainings in the development of materials.

Further studies, with wider scope, should be conducted to validate the results of this study.

\section{REFERENCES}

[1] D. M. Uychoco, "Academic reading proficiency of freshmen in the college of education of DMMMSU-SLUC: Input to the design of instructional modules for English 101,” JPAIR, vol. 9, 2012.

[2] E. V. Dechant, "Improving the teaching of reading," Prentice Hall of India, vol. 67, no. 13, pp. 10-31, 1969.

[3] G. Lui and C. Shun, "Outcome-based education and student learning in managerial accounting in Hong Kong,” Journal of Case Studies in Accreditation and Assessment, 2010.

[4] G. K. W. Wong and H. Y. Cheung, "Outcomes-based teaching and learning in computer science education at sub-degree level," International Journal of Information and Education Technology, vol. 1, no. $1,2011$.

[5] J. Biggs and C. Tang. (2006). Outcome-based teaching and learning (OBTL) what is it, why is it, how do we make it? [Online]. Available: https://www.ied.edu.hk/obl/files/pratical_guide_4.pdf

[6] K. Kennedy. (2009). Outcomes-based learning: concepts, issues and actions. The Hong Kong Institute of Education. [Online]. Available: http://www.ied.edu.hk/obl/files/OBLConcepts\%20Issues\%20and\%20 Action_Kennedy.doc

[7] M. Cerce-Murcia, Teaching English as a Second or Foreign Language, 3rd ed. Cengage Learning Inc., 2006, pp. 171-187.

[8] M T. N. Manzano, "English language competence of teacher education students in Ilocos Sur,” Ed.D. dissertation, University of Northern Philippines, Vigan City, Ilocos Sur, 2014.

[9] M. T. B. Nardo and E. R. Hufana, "Development and evaluation of modules in technical writing," American Journal of Educational Research, vol. 2, no. 6, pp. 341-350, 2014.

[10] R. M. Crespo, D. Leony, C. D. Kloos, I. Gutiérrez, J. Najjar, M. Totschnig, B. Simon, M. Derntl, S. Neumann, and P. Oberhuemer, "Aligning assessment with learning outcomes in outcome-based education," in Proc. the Engineering Education Conference, Madrid, Spain, 2010.

[11] S. P. T. Malan, "The new paradigm of outcomes-based education in perspective,” Journal of Family Ecology and Consumer Sciences, vol 28, 2000.

[12] W. D. Spady, "Outcomes based education: An international perspective,” in Understanding Outcomes Based Education: Teaching 
and Assessment in South Africa, Johnnesburg: SAIDE \& Oxford University Press, 1998.

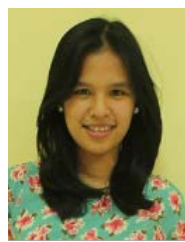

Jamaica B. Vizcarra is an instructor at the College of Teacher Education, University of Northern Philippines, Vigan City. She teaches professional subjects and major subjects under the English program. She finished her master of arts in education major in langauge and literature at Mariano Marcos State University, Laoag Ciy.

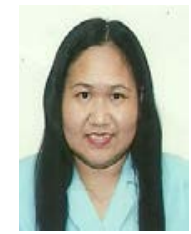

Jeanette G. Dials is an associate professor of the Mariano Marcos State University. She is the 2008 Metrobank outstanding teacher awardee, most outstanding school paper adviser of the Philippines in 2009, and former Head of the Provincial Education Department of the Provincial Government of Ilocos Norte. Her line of specialization includes language, literature, debate, journalism and research. She is one of the best paper presenters in the 2016 International Conference on Culture, Language and Literature in Singapore. 